\title{
METHODOLOGICAL ASPECTS OF RESEARCH OF VALUE PROBLEMS IN MODERN SOCIO-ECONOMIC CONDITIONS
}

\author{
МЕТОДОЛОГІЧНІ АСПЕКТИ ДОСЛІДЖЕННЯ ЦІННІСНОЇ ПРОБЛЕМАТИКИ \\ В СУЧАСНИХ СОЦІАЛЬНО-ЕКОНОМІЧНИХ УМОВАХ
}

\begin{abstract}
This article examines the problem of the crisis of the value system in modern society and examines the issues of methodological support of research on this topic. The article talks about the qualitative complexity of such an object of study as the social sphere of activity, which also includes even more complex issues of value problems.

The article talks about the significant impact of the value system on the results of human activity, which is particularly relevant in the context of modern socio-economic transformations. It also speaks of the important role of the human factor in the study of social processes. The article talks about the modern standard of thinking, the speed of all processes and the speed of their awareness by person. Attention is focused on the need to form a new paradigm of thinking in order to realize the possibilities for a person to master the latest knowledge and scientific technologies for their successful application in practice in modern conditions.

It is suggested that the solution of modern social problems using the stationary laws of the past era does not give the expected effect. The article presents a comparative description of the system methods of three generations with a justification of the degree of their suitability when studying issues of an individual's value system in a transitional period of social development. The fundamental contradiction of the level of systemic complexity of social issues and the level of systemic complexity of the methods of the first and second generations is pointed out.
\end{abstract}

As a result of the study, the limitations of the modern toolkit and its ineffectiveness in addressing the issues of forming a value system in the context of modern social challenges were revealed. Requirements were put forward for a method that can be used to describe modern social processes. A fundamentally new system concept has been proposed that is suitable for solving the complex issues of this problem. A proposal was made about the need to create conditions for the formation of a modern standard of thinking, the search for social technologies based on new methodological structures with the ability to effectively simulate any social phenomena and processes.

Key words: value system, cost problems, methodology, system methods.

У даній статті розглянута проблема кризи системи цінностей у сучасному суспільстві і вивчені питання методологічного забезпечення досліджень даної тематики. У статmі говориться про різноякісні складності такого об'єкта дослідження, як соціальна сорера діяльності, до якої також належать ще більш складні питання ціннісної проблематики.

У статmі сказано про значний вплив системи цінностей на результати діяльності людини, що є особливо актуальним в умовах сучасних соціально-економічних трансорормацій. Також йдеться про важливу роль людського фрактору в дослідженні сочіальних процесів. Сказано про найсучасніший стандарт мислення, швидкість протікання усіх процесів і швидкість їх усвідомлення людиною. Акцентовано увагу на необхідності формування нової парадигми мислення для реалізації можливостей освоєння людиною нових знань і наукових технологій для успішного застосування їх на практиці в сучасних умовах.

Висловлено припущення, що рішення сучасних соціальних завдань за допомогою стаціонарних законів минулої епохи не дає очікуваний ефект. У статті наведено порівняльну характеристику системних методів трьох поколінь з аргументованим обгрунтуванням ступеня їх придатності у процесі вивчення питань системи цінностей особистості в перехідний період суспільного розвитку. Зазначено на принциповому протиріччі рівня системної складності соціальної проблематики і рівня системної складності методів першого і другого поколінь.

у результаті проведеного дослідження було виявлено обмеженість сучасного інструментарію та його неерективність у вирішенні питань системи иінностей в умовах сучасних соціальних викликів. Висунуто вимоги до методу, який може застосовуватися для опису сучасних соціальних процесів. Запропоновано принципово нову системну концепцію, придатну для вирішення складних питань зазначеної проблематики. Висловлено пропозицію про необхідність створення умов для фрормування сучасного стандарту мислення, пошуку соціальних технологій, заснованих на нових методологічних конструкціях із можливістю ефективного моделювання будь-яких соціальних явищ і процесів.

Ключові слова: система цінностей, ціннісна проблематика, методологія, системні методu.
Formulation of the problem. The social field of activity belongs to the most complex field of research due to the high degree of unpredictability of human behavior. The system of values (SV) is a no less complex multi-quality object of scien- tific research. SV is manifested at the level of an individual, group or organization as a whole in the form of moral norms, in the structure of motivation and standards of behavior, affects the efficiency and level of development of human relations and 
their dynamics. "Choosing this or that value, a person thereby forms a plan for his behavior...", determines the future activity [3, p. 86]. It can be considered that the system of values in society is a set of restrictive and permissive norms regulating a person's vital activity.

Through a significant impact of the SV on the results of human activity in the conditions of socio-economic transformation, the issues of this problematic become especially relevant. In connection with the emergence of new, previously unknown knowledge and features of our time, this topic requires the latest modern research using methods that correspond to contemporary problems.

Analysis of recent research and publications. The genesis of the study of value problems in sociology comes from I. Kant. The study of the system of values, its structure and functions is the subject of many domestic and foreign scientific works and author's methodologies. Questions of value problematics were studied by such classics of sociology as M. Weber, E. Durkheim, G. Rickert, T. Parsons, P. Sorokin, R. Inglehart, M. Rokich, Sh. Schwartz. This topic was raised in the works of such famous contemporary authors as V.S. Bakirov, E. Golovakha, N. Panina, A.O. Ruchka, S.O. Makeev, L.G. Sokuryanskaya, O.N. Leontyev. Questions of values and value orientations were investigated by $\mathrm{K}$. Marks, U. Thomas, G. Simmel, N.F. Naumova, S.Ya. Matveev, V.B. Olshansky, V.O. Yadov, D.O. Leontyev, I.A. Surina and many others. In their works, the authors studied the formation of the system of values, its content and structure, considered the hierarchy of value preferences, the influence of various factors on its change. Many sociologists note that globalization and the openness of societies contribute to the transformation of value orientations and systems of value, the emergence of new patterns of behavior that are historically not characteristic of these social communities [10].

The study of value orientations and the determination of factors influencing their formation is especially important, since it allows to identify the emergence of social problems at the initial stage. However, the complete uncertainty of the processes taking place in modern society puts a person before the constant choice of their preferences. A person cannot fully rely on the system of value of the previous generation, since it (the system of value) seems to be inadequate in the context of modern social, political and economic transformations. In research papers published at the turn of the epoch, there is a unanimous opinion that there is a so-called "generational" conflict of values in society, a time lag and "historical inconsistency" of value orientations of the older generation to the demands of the time [2].

Given the speed of social change and the existence of a crisis of the system of value in mod- ern society, these works only partially give us an answer to the question of the content of value preferences in a given situation, the impact of the system of value on the effectiveness of human activity, the hierarchy of values of an individual and society as a whole point of view of the chronotope [7], etc. Therefore, the study of values is the main and constant problem of modern sociological science.

Purpose of the article. The purpose of this work is to conduct a comparative analysis of existing and search for new methodological tools suitable for the effective solution of complex issues of studying value problems in modern society.

The presentation of the main material. The main feature of the present time is the transitional period of development of the state, when there is a fundamental change in the ideological foundations of human existence of a bygone era and something new, previously unknown, appears.

The past epoch had a contemplative nature of human activity, in which a person was guided mainly by an empirical-emotional set of impressions of all participants in the activity process. Observation, as a sensually-intuitive knowledge of the world, subjectively reflects the existing reality in the consciousness of each individual. Any information, passing through the prism of individual qualities and characteristics of an individual, being exposed to external influence, is a kind of surrogate of the original product, the content of which depends on the personal opinion, emotional and physiological state of the interpreter.

Given the changing nature of human perception, the result of such activity will be in the nature of unpredictability. It is clear that under such conditions the implementation of constructive human activity is impossible. The lack of adequate ways to solve complex tasks in the period of global change inevitably leads to a decrease in the results of human activity to the level of its real capabilities. The latter is equivalent to the return of society to the level of that era, whose tasks correspond to this level of opportunity [6, p. 11]. It is obvious that under such conditions any active human activity will inevitably lead only to destructive results, which we now have in practice.

At present, the scientific world uses methods, the birth and formation of which took place in a relatively calm and stable society, for the events of which static character and the absence of abrupt changes were characteristic. This was acceptable and sufficient in a slow-moving contemplative era. In the modern, rapidly changing world, relying on old methods becomes not only unacceptable, but also dangerous for all living things on the Earth.

In crisis and in stationary conditions, all processes proceed in different ways. In the current crisis, the situation is changing very quickly and the person does not have enough time to suffi- 
ciently see what is happening, let alone understand it. Therefore, uncontrollable destabilizing processes occur around, which are also global in nature. The great minds of the past century V.I. Vernadsky, Pierre Teilhard de Chardin, etc. warned about this. This was also discussed at the World Conference on Sustainable Development in Rio de Janeiro in 1992 (namely, about the need to create a new paradigm of thinking).

Another reason for the ineffective action of stationary laws in times of crisis is the peculiarities of the so-called "assemblage point", in which all of humanity is now. The "assemblage point" is a change of epochs, a transition during which a significant change in outlook on life inevitably occurs, the ideological paradigm changes, a new stereotype of thinking is formed. All this leads to fundamental changes in the existing value system. "This phenomenon is called a revaluation of values, when there is a significant transformation of the existing value systems to fundamentally new ones that did not previously exist" [5, p. 46]. Such processes have a significant role in the fate of people, communities and even the state as a whole.

The solution of modern social problems with the help of the stationary laws of the past era does not give the expected effect today. Traditional methods are suitable for aspectual application and solution of simple one-way problems. But modern tasks are characterized by high dynamism and systemic complexity. While a person is trying to comprehend what is happening, the task in its implementation goes far ahead. There is a need to make a new decision in accordance with the new situation. The solution of any task requires a preliminary situational analysis, for the adequacy of which it is necessary to use such methodological tools that correspond to the level of complexity of the tasks to be solved. Selected funds should be based on scientific laws.

Social issues, having essentially an abstract nature, as an object of study belongs to the highest level of complexity. Due to the high social dynamics, it is practically impossible to adequately assess such processes and their consequences at the level of personal experience and existing theoretical support. This situation automatically leads to the problems of methodological support of modern social processes in general and in the sphere of value problems in particular.

The only theoretical means of supporting such processes was and is mathematics. Mathematics is a very concrete and static science, in which there is no place for a person. A person, unlike a technical device, has the right to make a choice at any time. But this "freedom of choice" is not provided for in mathematics, it cannot be taken into account in rigid mathematical formulas. The hard causal relationships of basic mathematical concepts lag far behind the dynamics of social processes. Society is dynamic, controversial and abstract. Mathematics can perfectly solve specific quantitative problems, but is powerless in a situation of interdisciplinary qualitative changes that constantly occur in the social sphere. What makes the system methods based on mathematics insufficient for solving complex social problems in modern society.

There was an urgent need to develop a special system formalism, more flexible and less structured than mathematics. This problem is still relevant. Therefore, to adequately address complex social issues, and even more so questions in the sphere of value problems, it is necessary to apply such methodological concepts that, according to the Ashby theorem [11], would contain the whole degree of diversity of the object under study. In other words, the level of the system complexity of the method should not be lower than the level of the system complexity of the object under study. Consequently, to describe modern social processes, it is necessary to apply system methods appropriate to their level of complexity.

The genesis of system theories shows three generations of system methods. The first generation of system methods includes the works of O.O. Bogdanov and L. Von Bertalanffy, which are limited by the verbal nature of their presentation. This makes it difficult to comprehend the material in the absence of the author. Accordingly, the use of these methods in practice is problematic. The second generation of system methods (Wiener N., Urmanzev Yu.A., Uemov A.I. and many others [8; 9] is limited to mathematics and the formalism of other sciences. This gave rise to many variants of system methodologies, which proved to be effective only in a narrow sphere of their applicability - in mathematics, physics, biology, etc. It was created about a hundred variants of system methods that differ in the definitions of the system, a symbolic description and depth of presentation [6]. All attempts to adequately display the basic positions of the system methods failed. Accordingly, the system methods of the second generation are also unable to adequately describe the complex processes occurring in society.

Professor Kenneth Bailey of the University of California, in his work "Sociology and Theories of New Systems", formulated 29 requirements for a new system methodology, which it must comply with [1]. New system methods fully comply with these requirements. These are system methods of the third generation. The third generation of system methods includes a new methodology based on the regularities of hyper-complex dynamic systems (GDS) [4]. The methodology basically contains universal system invariants, most of which are formulated for the first time. By its content and scope, this 
methodology is interdisciplinary, and by the method of construction it is open, which makes it acceptable for solving hierarchically complex social issues in modern conditions. This methodology allows replacing the traditional approach in modeling (retrospective) with a new type of modeling (perspective), which will allow to build a model not of an already existing object, but of an object that will be in perspective. This is possible in the case of a change in the existing retrospective analytical thinking of the past to the advanced synthetic thinking of the future. Synthetic thinking is the ability to perform a synthesis operation (addition) and the ability to model the future.

In this regard, it is necessary to create conditions for the formation of a modern standard of thinking, we need social technologies as products and algorithms based on new methodological structures. A new time, we need a new philosophy, which allows us to look at the world in a new way, with the ability to model social phenomena and processes far in advance.

Conclusions. Summarizing the above problems in solving complex contemporary problems in the field of sociology and issues of the system of value, we can talk about the urgent need to move from the usual methodological tools to new scientific technologies, which will be based on the basic laws of modern fundamental developments. Therefore, the system methods of the third generation can be considered potentially suitable for the effective solution of questions of value problems in the conditions of social and economic crisis.

\section{REFERENCES:}

1. Kennet Bejli. Sociologija i novye sistemnye teorii: $k$ teoreticheskomu sintezu. [Sociology and the New Systems Theory. Toward a Theoretical Synthesis]. Moscow, URSS, 1994. (in Russian).

2. Leont'ev D. A. Value as an interdisciplinary concept: Experience of multidimensional reconstruction. Sovremennyj socio-analiz. Sbornik statej [Modern socio-analysis. Digest of articles], Moskva, 1998. (in Russian).

3. Malahov V. Jetika [Ethics], Kiev, 1996, 88 p. (in Russian).

4. Maljuta A.N. Giperkompleksnye dinamicheskie sistemy [Hypercomplex dynamic systems]. Lviv : "Vyscha School", 1989. 118 p. ISBN 5-11-000571-0. (in Russian).

5. Maljuta A.N. Invariantne modeljuvannja: Kurs lekcij. Chastyna III: Vvedennja v Invariantne modeljuvannja. Lekcii' 21-30 [Invariant modeling: Course of lectures. Part 3: Introduction to Invariant Modeling. Lectures 21-30]. Chernihiv, TGI «Northern Star», 2010, 154 p. ISBN 123-7777-33-5 (in Ukrainian).

6. Maljuta A.N. Invariantne modeljuvannja: Kurs lekcij. Chastyna I: Vvedennja v Invariantne modeljuvannja. Lekcii' 1-10 [Invariant modeling: Course of lectures. Part 1: Introduction to Invariant Modeling. Lectures 1-10]. Chernihiv, TGI «Northern Star», 2010, 146 p. ISBN 123-7777-33-5 (in Ukrainian).

7. Politov A.V. The ontological meaning of the concept of chronotope in the philosophical ideas of A. Ukhtomsky and M. Bakhtin. Nauchnyj ezhegodnik Instituta filosofii i prava UrO RAN [Scientific Yearbook of the Institute of Philosophy and Law, Ural Branch of the Russian Academy of Sciences]. 2014, T. 14, Vol. 4, pp. 50-62. (in Russian).

8. Uemov A. I. Sistemnyj podhod i obshhaja teorija sistem [The system approach and the general theory of systems]. Moscow, Mysl Publishers, 1978, 272 p. (in Russian).

9. Urmancev Ju. A. Jevoljucionika, ili obshhaja teorija razvitija sistem prirody, obshhestva i myshlenija: nauchnoe izdanie [Evolyutsionika, or the general theory of the development of systems of nature, society and thinking: a scientific publication]. Izd. 2-e, pererab. i dop. Moscow, LIBROCOM Book House, 2009, 240 p. (in Russian).

10. Chutova N.P. Value orientations of modern Ukrainian youth: a sociological approach. Nova paradigma [New paradigm], 2019, Vol. 88, pp. 188-197. (in Russian).

11. Ashby U. Vvedenie $v$ kibernetiku [Introduction to Cybernetics]. Moscow, Foreign Literature Publishing House, 1959, 429 p. (in Russian). 